with the cost of living of representative working-class families (Liverpool: University Press. London : Hodder and Stoughton, Ltd. 1s.). A household consisting of father, mother and young children has been selected as representative, as well as a widow supporting two children of school age, and a husband. and wife, both old-age pensioners. Essential needs are sub-divided under the usual five heads : food, clothing, rent and rates, fuel and light, sundries. In regard to food, the findings of the report of the British Medical Association Committee on Nutrition have been taken as one basis, but the specimen diets were modified to satisfy rationing regulations and to permit greater variety in diet and elasticity in cooking. The poverty standard selected is that adopted for the Merseyside Survey. The report indicates that between June 1933 and October 1940, expenditures showed increases of $57 \cdot 5$ per cent, 64 per cent and 76 per cent respectively for the family, widow with children, and old-age pensioners.

Comparing the estimated basic needs of these representative families, poverty standards, actual expenditure, and income from the social services, the inquiry indicates that the services concerned succeed in finding a close approximation to the cost of bare subsistence, though this is appreciably below the human needs standard. The blot on the social services is the absence of adequate provision of assistance for sick persons and their families, and the reduction in benefit when work is lost on account of illness. The report includes an analysis of actual expenditure of three typical non-earning families as well as of the average expenditure of 8,905 families, and a comparison with human needs, which suggests that the British Medical Association diets are what they were intended to be, estimates of the minimum expenditure on food necessary for health and working capacity. The sums spent on rent, fuel and light in the average budget are also rather higher than those allotted on the human needs standard, but the difference between the two results under the head of clothing is insignificant. The total average household expenditure revealed in the budgets collected by the Ministry of Labour is 50 per cent higher than the estimated cost of living at the human needs level.

\section{Hindu Iconography}

A valUaBLE collection of paintings and bronzes of international repute illustrating Indian art and religion has recently been added to the national collections by donation to the Department of Oriental Antiquities of the British Museum (Bloomsbury). It has been given by Mrs. E. C. Moor and was formed by her husband's grandfather, Major Edward Moor, F.R.S. (1771-1848), while gathering material for his pioneer work "The Hindu Pantheon" (1810). The collection consists of 609 objects, of which 360 are bronzes and 249 are paintings and drawings. The paintings, which with the bronzes were for the most part acquired through a pandit of Foona, to whom Moor refers and who identified the subjects, are Decani in style. Some belong to an eighteenth century Rajput school, while the most important illustrate verses by the poet Kesava Das of Bundelkund (1555-1617) and were probably executed at Jaipur in the early eighteenth century. The majority of the bronzes are of seventeenth century or eighteenth century date. The value of the collection lies in its original purpose as illustrating Hindu iconography; and as is pointed out in an account of the collection (Brit. Mus. Quarterly, 14, 4 ; 1940), since not all of them were used in "The Hindu Pantheon" and those that were engraved for publication were "made more handsome", there is room for much fresh work on the collection. It is hoped that it will provide the nucleus of a study collection for students of Indian art and religion.

\section{Birds of North-West England}

A IIST of 270 species and five subspecies together with much original information on bird habits and movements resulting from some twenty years fieldstudy of bird life in the area between the Ribble and the Dee and inland to Warrington were given on February 13 in a paper to the Liverpool University Biological Society by Mr. Eric Hardy, an honorary member, who reviewed the results as they had been drawn up for the Merseyside Naturalists' Association's proposed handbook on the birds of the area. Much of this work might seem idle in war-time, but the bird census and survey have disclosed items of economic importance such as the distribution and habits of useful and harmful birds on the land, which are being sent to the Royal Lancashire Agricultural Society. The increase in the distribution of wild duck, waders, gulls, crows, owls, etc., and the decrease of other birds is of more than natural history interest.

The bird census showed an average density of $6 \cdot 7$ birds to the acre; the house-sparrow, which forms 38 per cent of the bird population of a Liverpool suburban park, forms only 2 per cent of the population of rural Knowsley Park. Mr. Hardy pointed out that a knowledge of the economic position of bird life in an area is essential to war-time agricultural efforts in order to know what to protect and what to repress -an undertaking too often treated from a national rather than a local attitude. It has often been stated that we could not live more than nine years without birds owing to the ravages of insect pests they control; but modern field work has shown that a greater toll of insect pests like caterpillars is taken by predatory insects.

\section{Spike Disease of Sandal}

THE spike disease of sandal was first noticed forty years ago and since then numerous investigators have studied the problem. For the most recent account of the disease the reader is referred to an article by Rao Sahib S. R. Iyengar and A. L. Griffith (Indian Forest Records, 6, No. 4). Work so far carried out has led to the conclusion that it is an insectborne disease. The vector is of such a size that it can pass through a mesh of $t$ in. but is excluded by 